của Bingqian Zhang (2019) [7]. Do đó chưa thấy được khác biệt về tỉ lệ có thai giữa các nhóm giá trị AMH thấp và trung bình. Chúng tôi hy vọng tiến hành nghiên cứu với cõ̃ mẫu lớn hơn để tìm hiểu sâu hơn về vấn đề này.

\section{KẾT LUÂ̂N}

- Tỉ lệ noãn trưởng thành, tỉ lệ thụ tinh, tỉ lê phôi khả dụng ở giai đoạn phân cắt không có khác biệt giữa các nhóm AMH. Tuy nhiên số lượng noãn, số lượng phôi và số lượng phôi khả dụng khác biệt giữa các nhóm là có ý nghĩa: thấp nhất ở nhóm AMH thấp và cao nhất ở nhóm $\mathrm{AMH}$ cao.

- Nhóm AMH cao có tỷ lệ thai lâm sàng cao hơn có ý nghĩa so với hai nhóm còn lại. Tỉ lệ thai lâm sàng của nhóm $\mathrm{AMH}$ trung bình cao hơn nhóm AMH thấp nhưng không có ý nghĩa thống kê.

- AMH không có giá trị dự đoán chất lượng noãn bào nhưng có khả năng dự đoán được số noãn thu được, số phôi khả dụng và tỉ lệ thai lâm sàng.

\section{Lờ' CẢM ƠN}

Chúng tôi trân trọng gửi lời cảm ơn đến ban lãnh đao, quý thây cô, đồng nghiệp tại Trung tâm Hổ trợ sinh sản và Công nghệ mô ghép, Bênh viện Đại học Y Hà Nội đã tạo điều kiện và giúp đỡ để chúng tôi hoàn thành nghiên cứu này. Các tác giả cam kết không có tranh chấp về quyền lợi.

\section{TÀI LIÊU THAM KHẢO}

1. Vương Thị Ngọc Lan (2016). Giá trị xét nghiệm AMH,FSH và AFC dự đoán đáp ứng buồng trứng trong thụ tinh ống nghiệm. Luận văn Tiến sỹ y học, Đại học Y Dược Hồ Chí Minh, 186.

2. Broekmans F.J., Kwee J., Hendriks D.J., et al. (2006). A systematic review of tests predicting ovarian reserve and IVF outcome. Hum Reprod Update, 12(6), 685-718.

3. Xu H., Zeng L., Yang R., et al. (2017). Retrospective cohort study: $\mathrm{AMH}$ is the best ovarian reserve markers in predicting ovarian response but has unfavorable value in predicting clinical pregnancy in $\mathrm{GnRH}$ antagonist protocol. Arch Gynecol Obstet, 295(3), 763-770.

4. ALPHA Scientists In Reproductive Medicine and ESHRE Special Interest Group Embryology (2011). Istanbul consensus workshop on embryo assessment: proceedings of an expert meeting. Reprod Biomed Online, 22(6), 632-646.

5. Zegers-Hochschild F., Adamson G.D., de Mouzon J., et al. (2009). The International Committee for Monitoring Assisted Reproductive Technology (ICMART) and the World Health Organization (WHO) Revised Glossary on ART Terminology, 2009. Human Reproduction, 24(11), 2683-2687.

6. Kelsey T.W., Wright P., Nelson S.M., et al. (2011). A validated model of serum anti-müllerian hormone from conception to menopause. PLOS ONE, 6(7), e22024.

7. Zhang B., Meng Y., Jiang $X$., et al. (2019). IVF outcomes of women with discrepancies between age and serum anti-Müllerian hormone levels. Reprod Biol Endocrinol, 17(1), 58.

8. Dai X., Wang Y., Yang H., et al. (2020). AMH has no role in predicting oocyte quality in women with advanced age undergoing IVF/ICSI cycles. Sci Rep, 10(1), 19750.

9. Eldar-Geva T., Ben-Chetrit A., Spitz I.M., et al. (2005). Dynamic assays of inhibin $B$, antiMullerian hormone and estradiol following $\mathrm{FSH}$ stimulation and ovarian ultrasonography as predictors of IVF outcome. Human Reproduction, 20(11), 3178-3183.

\title{
KIẾN THỨC VÀ THỰC HÀNH VỀ PHÒNG CHỐNG BÊNH RĂNG MIỆNG CỦA HỌC SINH HAI TRƯỜNG TIỂU HỌC THÀNH PHỐ ĐIỆN BIÊN PHỦ, TỈNH ĐIỆN BIÊN NĂM 2018
}

\section{TÓM TẮT}

Một nghiên cứu cắt ngang tiến hành trên 381 hoc sinh 2 trường tiểu học trên địa bàn thành phố Điệ̉n Biên Phủ, tỉnh Điên Biên từ tháng 7/2018 đến tháng 2/2019. Mục tiêu của nghiên cứu nhằm xác định kiến thức, thực hành về phòng chống bệnh răng miệng của

*Trường Đại hơ Y Dược Thái Binh

Chịu trách nhiệm chính: Ngô Văn Mạnh

Email: manhsdh@gmail.com

Ngày nhận bài: 28.7.2021

Ngày phản biên khoa hoc: 27.9.2021

Ngày duyệt bài: 4.10 .2021
Ngô Văn Mạnh*, Lê Đức Cường*

học sinh tiểu học. Kết quả nghiên cứu cho thấy: Có $36,9 \%$ hoc sinh biết cách là chải răng xoay tròn. Có $86,2 \%$ các em học sinh biết phòng tránh sâu răng bằng cách chải răng hằng ngày, ăn ít đồ ngọt chiếm tỷ lệ $61,2 \%$, súc miệng chiếm tỷ lệ $46,3 \%$ và khám răng thường xuyên là $36,6 \%$. Số hoc sinh chải răng 2 lần/ngày chiếm tỷ lệ $67,1 \%, 36,7 \%$ chải răng xoay tròn, có $54,2 \%$ học sinh 2 trường sử dụng đồ ngọt 1 đến 3 lần/ ngày.

Tư khóa: học sinh tiểu học, bệnh răng miệng, Điện Biên

\section{SUMMARY}

KNOWLEDGE AND PRACTICE ABOUT DENTAL 


\section{DISEASE PREVENTION AMONG PUPUILS OF TWO PRIMARY SCHOOLS IN DIEN BIEN CITY, DIEN BIEN PROVINE IN 2018}

A cross-sectional study was conducted on 381 pupils from 2 primary schools in Dien Bien Phu city, Dien Bien province from July 2018 to February 2019. The aim of the study was to determine the knowledge and practice of oral disease prevention of primary school pupils. Results of the study showed that: There was $36.9 \%$ of pupils know how to brush their teeth by circular motion. There was $86.2 \%$ of pupils know how to prevent tooth decay by brushing their teeth daily. Proportion of pupils' knowledge of eating less sweet food was $61.2 \%$, mouthwash was $46.3 \%$ and regular dental check-up was $36.6 \%$. The number of pupils brushing their teeth twice a day accounted for $67.1 \%$; $36.7 \%$ of pupils brushing their teeth in a circular motion, $54.2 \%$ of pupils in 2 schools used sweets from 1 to 3 times a day.

Keywords: pupils primary school, dental disease, Dien Bien

\section{I. ĐĂT VẤN ĐỀ}

Trẻ em ở lứa tuổi tiểu học có hê răng hỗn hợp (vừa có răng sữa vừa có răng vĩnh viễn) nên việc chăm sóc, giữ gìn vệ sinh răng miệng là hết sức cần thiết. Vì trong giai đoạn này răng vĩnh viễn lần lượt mọc thay thế cho răng sữa. Răng sữa rụng đúng ngày, không bị sâu hay nhổ sớm thì răng vĩnh viễn sẽ mọc lên đúng chỗ, đều và đep. Do đó, để tránh bệnh sâu răng và viêm nướu cho học sinh ở lứa tuổi này việc chăm sóc giữ gìn sức khỏe răng miêng là rất quan trọng. Phòng bệnh răng miệng là quá trình tương đối đơn giản, không phức tạp, không đòi trang thiết bị đắt tiền, không đòi hỏi cán bộ kỹ thuật chuyên môn cao, chi phí thấp, dễ thựcc hiện tại cộng đồng. Do đó, phòng bệnh răng miêng sớm ngay ở lứa tuổi hoc sinh là chiến lược khả thi nhất đã được WHO triển khai. Tuy nhiên, vấn đề chăm sóc sức khỏe răng miênng học đường ở Việt Nam chưa được đầu tư đúng mức khi cơ sở hạ tầng phục vụ cho chăm sóc sức khỏe răng miệng cho học sinh còn rất hạn chế, nhiều trường tiểu học chưa có phòng nha học đường. Do đó, tỷ lệ mắc các bệnh răng miệng ở trẻ em vẫn còn rất cao, Theo số liêu từ Bênh Viên Răng Hàm Mặt Hà Nôii, tỷ lệ sâu răng ở lứa tuổi từ 6 - 12 tuổi chiếm trên $85 \%$ (trung bình mỗi trẻ em lứa tuổi học đường thường có 5-6 răng sâu) [1]. Để phòng tránh các bệnh răng miênng thì kiến thức và thực hành của trẻ về chăm sóc răng miệng là rất quan trọng. Nghiên cứu này được tiến hành với mục tiêu: Mô tả kiến thức, thực hành của học sinh 2 trường tiểu học tại Thành phố Điện Biên năm 2018.

\section{II. ĐỐI TƯỢNG VÀ PHƯƠNG PHÁP NGHIÊN CỨU 2.1. Địa điểm, thời gian, đối tượng}

nghiên cứu

- Địa điểm nghiên cứu: được thực hiện tại 2 trường tiểu học tại thành phố Điên Biên Phủ tỉnh Điên Biên. Bao gồm: Trường tiểu học Hà Nội và trường tiểu học Noong Bua.

- Đối tượng nghiên cứu: Học sinh của hai trường tiểu học tai địa bàn nghiên cứu. Tiêu chuẩn loại trừ: Các học sinh từ chối tham gia nghiên cứu, các học sinh vắng học tại thời điểm nghiên cứu.

- Thời gian nghiên cứu: Nghiên cứu được tiến hành từ tháng 7/2018 đến tháng 2/2019.

\subsection{Phương pháp nghiên cứu}

\subsubsection{Thiết kế nghiên cứu}

Nghiên cứu được thiết kế theo phương pháp mô tả thông qua cuộc điều tra cắt ngang có phân tích.

2.2.2. Cỡ mẫu và phương pháp chọn mẫu a) Cỡ mẫu nghiên cứu

$$
\mathbf{n}=\mathbf{Z}_{\left(1-\frac{\alpha}{2}\right)}^{2} \times \frac{\mathrm{p}(1-\mathrm{p})}{\mathrm{d}^{2}}
$$

Trong đó: a: Mức ý nghĩa thống kê ( $\mathrm{a}=$ $0,05) ; Z_{(1-a / 2)}:$ Giá trị $Z$ thu được tương ứng với $\mathrm{a}=0,05 ; \mathrm{Z}_{(1-\mathrm{a} / 2)}=1,96 ; \mathrm{d}$ : Sai số tuyêt đối, trong nghiên cứu này chon $d=0,045$; $p$ : tỳ lê học sinh tiểu học mắc các bệnh răng miệng) bằng 0,77 theo nghiên cứu của Trần Tấn Tài năm 2016[2]

Thay vào công thức tính được cõ̃ mẫu là 336 học sinh, trên thực tế điều tra: 381 học sinh.

\section{b) Phương pháp chọn mấu}

+ Chon trường: Lập danh sách tất cả các trường tiểu học trên địa bàn thành phố Điện Biên Phủ, tỉnh Điện Biên. Sau đó bốc thăm ngẫu nhiên 2 trường để điều tra.

+ Chọn học sinh nghiên cứu: Mỗi trường bao gồm 5 khối lớp từ lớp 1 đến lớp 5 . Tại mỗi trường tiến hành điều tra 180 học sinh ở tất cả các khối lớp, do đó mỗi khối chọn ngẫu nhiên 1 lớp để đưa vào nghiên cứu.

\subsection{Phương pháp thu thập thông tin}

Công cụ thu thập thông tin: Phiếu điêu tra đã được chuẩn bị sẵn, gồm 3 phần: thông tin chung về đối tượng nghiên cứu, kiến thức về chăm sóc răng miệng (gồm 10 câu), thực hành về chăm sóc răng miệng (10 câu).

Kỹ thuật thu thập thông tin: điều tra viên đọc từng câu hỏi trong phiếu điều tra để học sinh hiểu và trả lời. Sau khi học sinh điền xong câu thứ nhất thì chuyển sang câu thứ hai và tiếp tục cho đến câu hỏi cuối cùng.

\subsection{Một số biến số trong nghiên cứu}

- Thông tin chung về học sinh

- Thông tin về kiến thức thực hành: tỷ lê biết nguyên nhân sâu răng, tỷ lệ biết hậu quả của 
sâu răng, tỷ lệ biết hậu quả của sâu răng, tỷ lệ biết cách phòng bênh, tỷ lệ học sinh biết cách chải răng, tỷ lệ biết các loại thức ăn có hại cho răng, số lần đi khám răng, tỷ lệ có chải răng, tần saust sử dụng đồ ngọt

2.5. Phương pháp xử lý số liệu. Số liệu thu thập được nhập liệu kép bằng phần mềm EpiData 3.0. Các số liệu sau khi thu thập, được tổng hợp và xử lý bằng phần mềm SPŚS 22.0.Tính tỷ suất chênh OR; $95 \% \mathrm{CI}$ của OR để xác định một số yếu tố liên quan đến bệnh răng miệng của học sinh.

\section{KẾT QUẢ NGHIÊN CỨU}

3.1 Kiến thức về phòng bệnh răng miệng của học sinh tiểu học

\section{Bảng 3.1. Kiến thức của hoc sinh về nguyên nhân sâu răng $(n=376)$}

\begin{tabular}{|c|c|c|c|c|c|c|c|}
\hline \multirow{2}{*}{ Nguyên nhân } & \multicolumn{2}{|c|}{$\begin{array}{l}\text { Hà Nội - Điện } \\
\text { Biên }(n=196)\end{array}$} & \multicolumn{2}{|c|}{$\begin{array}{c}\text { Noong Bua } \\
(\mathrm{n}=\mathbf{1 8 0})\end{array}$} & \multicolumn{2}{|c|}{ Chung $(n=376)$} & \multirow[b]{2}{*}{ P } \\
\hline & $\mathbf{S L}$ & $\%$ & SL & $\%$ & $\mathbf{S L}$ & $\%$ & \\
\hline Ân nhiêu kẹo bánh & 131 & 66,8 & 145 & 80,6 & 276 & 73,4 & $<0,05$ \\
\hline Không chải răng & 155 & 79,1 & 76 & 42,2 & 231 & 61,4 & $<0,05$ \\
\hline Không biết & 4 & 2,0 & 13 & 7,2 & 17 & 4,5 & $<0,05$ \\
\hline
\end{tabular}

Bảng 3.1 cho thấy kiến thức của học sinh về nguyên nhân sâu răng là do ăn nhiều bánh kẹo chiếm tỳ lệ cao nhất $73,4 \%$, tiếp đến là không chải răng chiếm $61,4 \%$.

Bảng 3.2. Kiến thức cưa học sinh về tác hại cưa sâu răng $(n=376)$

\begin{tabular}{|c|c|c|c|c|c|c|c|}
\hline \multirow[t]{2}{*}{$\begin{array}{l}\text { Trường } \\
\end{array}$} & \multicolumn{2}{|c|}{$\begin{array}{l}\text { Hà Nội - Điện } \\
\text { Biên }(n=196 \hat{)}\end{array}$} & \multicolumn{2}{|c|}{$\begin{array}{c}\text { Noong Bua } \\
(n=180)\end{array}$} & \multicolumn{2}{|c|}{ Chung $(n=376)$} & \multirow{2}{*}{ p } \\
\hline & $\mathbf{S L}$ & $\%$ & SL & $\%$ & $\mathbf{S L}$ & $\%$ & \\
\hline Đau răng & 169 & 86,2 & 126 & 70,0 & 295 & 78,5 & $<0,05$ \\
\hline Răng có lô đen & 66 & 33,7 & 82 & 45,6 & 148 & 39,4 & $<0,05$ \\
\hline Mất răng & 51 & 26,0 & 83 & 46,1 & 134 & 35,6 & $<0,05$ \\
\hline Không biết & 5 & 2,6 & 22 & 12,2 & 27 & 72 & $<0,05$ \\
\hline
\end{tabular}

Bảng 3.2. cho thấy đa số các học sinh biết tác hại của sâu răng gây đau răng là $78,5 \%$, làm cho răng có lô̂ đen là $39,4 \%$ và mất răng là $35,6 \%$. Tỷ lệ học sinh trường Hà Nội- Điện Biên biết hậu quả của sâu răng là đau răng chiếm $86,2 \%$ còn ở học sinh trường Noong Bua là $70,0 \%$. Sự khác biệt này là có ý nghĩa thống kê với $p<0,05$.

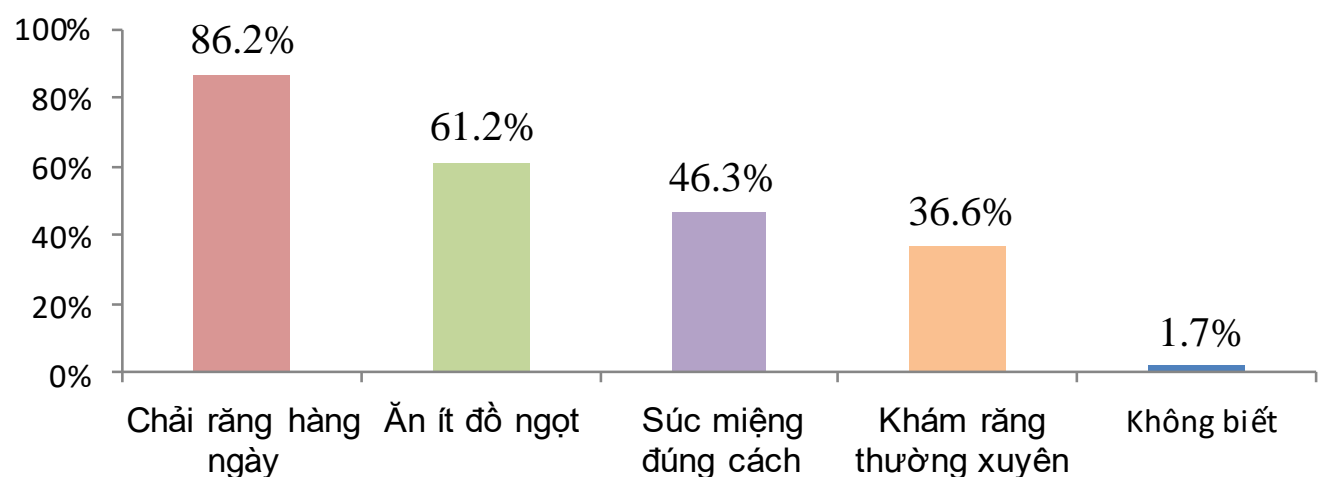

Biểu đồ 3.1: Kiến thức của học sinh về cách phòng tránh bệh sâu răng $(n=376)$

Biểu đồ 3.1 cho thấy: $86,2 \%$ các em học sinh biết phòng tránh sâu răng bằng cách chải răng hằng ngày - chiếm tỷ lệ cao nhất, tiếp đến là ăn ít đồ ngọt chiếm tỷ lệ $61,2 \%$, súc miệng chiếm tỷ lệ $46,3 \%$ và khám răng thường xuyên là $36,6 \%$

Bảng 3.3. Kiến thức cửa học sinh về cách chải răng $(n=376)$

\begin{tabular}{|c|c|c|c|c|c|c|c|}
\hline \multirow[b]{2}{*}{ Cách chải răng } & \multicolumn{2}{|c|}{$\begin{array}{l}\text { Hà Nội - Điệ̂n } \\
\text { Biên }(n=196)\end{array}$} & \multicolumn{2}{|c|}{$\begin{array}{c}\text { Noong Bua } \\
(n=180)\end{array}$} & \multicolumn{2}{|c|}{$\begin{array}{c}\text { Chung } \\
(n=376)\end{array}$} & \multirow{2}{*}{$\mathbf{p}$} \\
\hline & SL & $\%$ & SL & $\%$ & $\mathbf{S L}$ & $\%$ & \\
\hline Chải doc thân răng & 24 & 12,2 & 40 & 22,2 & 64 & 17,0 & \\
\hline Chải ngang thân răng & 86 & 43,9 & 60 & 33,3 & 146 & 38,8 & \\
\hline Chi chải mặt nhai & 6 & 3,1 & 6 & 3,3 & 12 & 3,2 & $<0,05$ \\
\hline Chải xoay tròn & 80 & 40,8 & 69 & 38,3 & 149 & 39,6 & \\
\hline Không biết & 0 & 0 & 5 & 2,8 & 5 & 1,3 & \\
\hline
\end{tabular}


Bảng 3.3 cho thấy, cách thức chải răng mà các em học sinh biết nhiêu nhất là chải răng xoay tròn (chiếm 39,6\%) và chải ngang thân răng (chiếm 38,8\%).

3.2 Thực hành về phòng chống bệnh răng miệng

Bảng 3.4. Số lần chải răng trong ngày của học sinh theo trường $(n=381)$

\begin{tabular}{|c|c|c|c|c|c|c|c|}
\hline \multirow{2}{*}{ Số lân } & \multicolumn{2}{|c|}{$\begin{array}{c}\text { Hà Nội - Điện Biên } \\
(\mathrm{n}=\mathbf{1 9 7})\end{array}$} & \multicolumn{2}{|c|}{$\begin{array}{c}\text { Noong Bua } \\
(n=184)\end{array}$} & \multicolumn{2}{|c|}{ Chung } & \multirow{2}{*}{$\mathbf{p}$} \\
\hline & $\mathbf{S L}$ & $\%$ & SL & $\%$ & SL & $\%$ & \\
\hline Không & 3 & 1,5 & 4 & 2,2 & 7 & 1,9 & \multirow{4}{*}{$>0,05$} \\
\hline 1 lần/ngày & 46 & 23,6 & 37 & 20,7 & 83 & 22,2 & \\
\hline 2 lần/ngày & 132 & 67,7 & 119 & 66,5 & 251 & 67,1 & \\
\hline$\geq 3$ lần/ngày & 14 & 7,2 & 19 & 10,6 & 33 & 8,8 & \\
\hline
\end{tabular}

Qua bảng 3.4, số học sinh chải răng 2 lần/ngày chiếm tỷ lệ cao nhất với $67,1 \%$. Bên cạnh đó có $22,2 \%$ học sinh chải răng 1 lần/ngày và $8,8 \%$ học sinh chải răng trên 3 lần/ngày.

Bảng 3.5. Thực hành chái răng của học sinh $(n=381)$

\begin{tabular}{|c|c|c|c|c|c|c|c|}
\hline & \multicolumn{2}{|c|}{$\begin{array}{c}\text { Hà Nội - Điện Biên } \\
(\mathrm{n}=197)\end{array}$} & \multicolumn{2}{|c|}{$\begin{array}{c}\text { Noong Bua } \\
(n=184)\end{array}$} & \multicolumn{2}{|c|}{$\begin{array}{c}\text { Chung } \\
(\mathrm{n}=381)\end{array}$} & \multirow[t]{2}{*}{$\mathbf{p}$} \\
\hline & $\mathbf{S L}$ & $\%$ & $\mathbf{S L}$ & $\%$ & $\mathbf{S L}$ & $\%$ & \\
\hline Chải dọc thân răng & 23 & 11,7 & 46 & 25,0 & 69 & 18,1 & \\
\hline Chải ngang thân răng & 83 & 42,1 & 77 & 41,8 & 160 & 42,1 & 5005 \\
\hline Chỉ chải mặt nhai & 9 & 4,6 & 3 & 1,6 & 12 & 3,1 & $<0,0\rangle$ \\
\hline Chải xoay tròn & 82 & 41,6 & 58 & 31,5 & 140 & 36,7 & \\
\hline
\end{tabular}

Bảng 3.5 cho thấy có $42,1 \%$ họ sinh chải răng ngang thân răng và có $36,7 \%$ chải răng xoay tròn. Tỳ lệ học sinh trường Hà Nội-Điện Biên chải ngang thân răng và chải xoay tròn (lần lượt là $42,1 \%$ và $41,6 \%)$. Trong khi đó các tỷ lệ tương ứng ở học sinh trường Noong Bua là $41,8 \%$ và $31,5 \%$. Sự khác biệt về thực hành chải răng giữa học sinh hai trường là có ý nghĩa thống kê $(p<0,05)$.

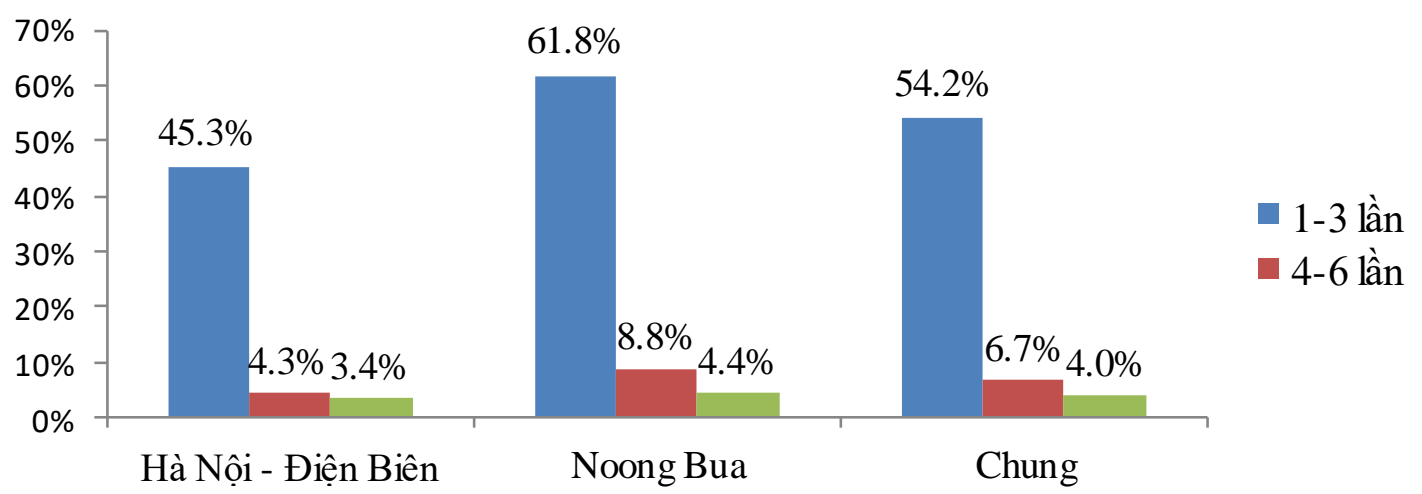

Biểu đồ 3.2: Tân suất sử dụng đồ ngọt của học sinh $(n=253)$

Biểu đồ 3.2 thể hiện tần suất sử dụng đồ ngọt của học sinh 2 trường Hà Nội- Điện Biên và Noong Bua. Có $54,2 \%$ học sinh 2 trường sử dụng đồ ngọt 1 đến 3 lần trên ngày, 6,7\% sử dụng 4 đến 6 lần trên ngày và 4,0\% sử dụng trên 6 lần.

\section{BÀN LUẬN}

Về nguyên nhân gây sâu răng, có $73,4 \%$ các em cho rằng là do ăn nhiều đồ ngọt và có $61,4 \%$ là do không chải răng. Tỷ lệ này trong nghiên cứu của Nguyễn Ngọc Nghĩa tại Yên Bái năm 2009 trên đối tượng là học sinh tiểu học lần lượt là $54,1 \%$ và $30,2 \%$ đều thấp hơn so với trong nghiên cứu của chúng tôi [3]. Điều này có thể do Yên Bái mẫu lựa chọn có nhiều các em học sinh lớp 1 , lớp 2 và lớp 3 , do đó nhận thức còn nhiều hạn chế. Tuy nhiên, kết quả này lại thấp hơn so với nghiên cứu của tác giả Mai Thị Liên năm 2013 với học sinh cho rằng nguyên nhân do ăn bánh kẹo là $86,3 \%$ và ăn xong không chải răng là $68,5 \%$ [4]. Khi được hỏi về tác hại của sâu răng, đa phần các em đều biết tác hại của sâu răng là đau răng $(78,5 \%)$, một số cho rằng răng sẽ có lỗ đen $(39,4 \%)$ và mất răng $(35,6 \%)$. Việc hiểu rõ về tác hại đâu tiên của sâu răng sẽ có vai trò rất lớn trong việc giúp các em học sinh nhận biết được các triệu chứng ban đầu, từ đó các em có thể phản ánh lại cho phụ huynh để có thể 
được đưa đi khám và điều trị kịp thời. Biểu đồ 3.1. cho thây có $86,2 \%$ học sinh chọn cách đánh răng hàng ngày, $61,2 \%$ cho rằng không nên ăn đồ ngọt, $46,3 \%$ chọn súc miệng đúng cách và chỉ có $36,6 \%$ cho rằng cần khám răng thường xuyên. Kết quả này có thấp hơn so với kết quả nghiên cứu của Mai Thị Liên năm 2013 tại Nam Định với tới $84,4 \%$ học sinh cho rằng cần phải vệ sinh răng miệng sạch sẽ; $79,3 \%$ học sinh cho rằng cần phải đi khám răng [4]. Kiến thức về cách chải răng của các em học sinh vẫn còn nhiều hạn chế, khi chỉ có 39,6\% các em lựa chọn phương thức chải răng đúng - chải răng xoay tròn, kết quả này thấp hơn so với nghiên cứu của Nguyễn Hữu Thiện tiến hành trên đối tượng học sinh lớp 4 tại Thái Bình năm 2016 khi có $70,1 \%$ các em lựa chọn cách chải răng xoay tròn [5].

Về thực hành chải răng, tỷ lệ học sinh chải răng hai lần/ngày chiếm tỷ lệ cao nhất là $67,1 \%$, chải răng một lần/ngày chiếm $22,2 \%$ và chải răng trên ba lần/ngày chỉ chiếm $8,8 \%$. Kết quả này tương tự với kết quả nghiên cứu năm 2010 của Đào Lê Nam Trung và cộng sự tại Hà Nội, với $74 \%$ học sinh đánh răng ít nhất hai lần/ngày[6]. Thói quen ăn, uống đồ ngọt như đường, bánh kẹo của HS là một vấn đề thường gặp đặc biệt là học sinh tiểu học, có nhiều em còn mang cả bánh kẹo, sữa tươi đến lớp trong khi đó vệ sinh răng lại rất kém, thói quen này có mối liên quan mật thiết với bệnh sâu răng. Việc thực hành chải rắng của học sinh chủ yếu là chải răng ngang thân răng $(42,0 \%)$ và chải răng xoay tròn $(36,7 \%)$. Tỷ lệ chải răng theo thân răng trong nghiên cứu của chúng tôi tương tự như kểt quả nghiên cứu của Đào Lê Nam Trung và cộng sự năm 2010 tại Hà Nội với tỷ lệ 46,6\% cũng như nghiên cứu của Mai Thị Liên năm 2013 tại Nam Định với tỷ lệ $32 \%$. Việc thực hành chải răng theo vòng tròn vẫn còn thấp, ở nghiên cứu của Đào Lê Nam Trung và cộng sự chỉ là $6,4 \%$ và của Mai Thị Liên là $12,6 \%[4,6]$. Lý giải cho nguyên nhân này, có thể thấy rằng chải răng ngang thân răng là một thói quen gặp ở rất nhiều người Việt Nam, cả người lớn cũng thường chải răng theo cách này, từ đó dẫn tới việc hướng dần cho trẻ sai cách. Nếu không được hướng dẫn thực hành đúng cũng như xây dựng được thói quen thì việc chải răng sai cách vẫn cứ diễn ra, chính vì vậy, tỷ lệ chải răng đúng cách ở nghiên cứu của chúng tôi vẫn còn thấp. Tần suất sử dụng đồ ngọt của học sinh chủ yêu từ 1 đên 3 lần/ngày (chiếm 54,2\%), từ 4 đến 6 lần/ngày là $6,7 \%$, thấp hơn so với kết quả nghiên cứu của
Đào Lê Nam Trung và cộng sự tại Hà Nội năm 2010 khi có tới 90,7\% học sinh ăn đồ ngọt 1 đến 3 lần/ngày [6].Việc sử dụng đồ ngọt nhiều ở lứa tuổi học sinh đang ngày càng trở nên phổ biến, không chỉ ở những nơi có điều kiện kinh tế phát triển. Việc ăn uống đồ ngọt quá nhiều như bánh kẹo, nước ngọt có gas... đang là nguyên nhân gâyy nên những bệnh lý răng miệng ở trẻ. Tuy nhiên, nếu công tác truyền thông về vệ sinh răng miệng tốt, cũng như việc hướng dẫn thực hành, giúp trẻ xây dựng thói quen vệ sinh răng miệng của nhà trường và gia đình được phát triển sâu rộng, thì sức khỏe răng miệng của trẻ vẫn có thể được đảm bảo.

\section{KẾT LUÂN}

Kiến thức và thực hành của học sinh 2 trường tiểu học tại thành phố Điện Biên còn hạn chế, Có $36,9 \%$ học sinh biết cách là chải răng xoay tròn. Có $86,2 \%$ các em học sinh biết phòng tránh sâu răng bằng cách chải răng hằng ngày, ăn ít đồ ngọt chiếm tỷ lệ $61,2 \%$, súc miêng chiếm tỷ lê $46,3 \%$ và khám răng thường xuyên là $36,6 \%$. Số học sinh chải răng 2 lần/ngày chiếm tỷ lệ $67,1 \%$, $36,7 \%$ chải răng xoay tròn, có $54,2 \%$ học sinh thường sử dụng đồ ăn ngọt. Cần có những giải pháp truyền thông giáo dục sức khoẻ để nâng cao kiến thức và thực hành của học sinh

\section{TÀI LIÊU THAM KHẢO}

1. Viện Răng Hàm Mặt Hà Nội, Báo cáo tổng kết hội nghị nha học đường hàng năm các tính phía Bẳc. 2005.

2. Trân Tấn Tài, Thực trạng bệnh sâu răng và hiệu quả của giải pháp can thiệp cộng đồng của học sinh tại một số trường tiểu học ở Thửa Thiên Huế. 2016, Trướng Đai hoc Y Dước Huế.

3. Nguyển Ngọc Nghĩa, Nghiên cứu thực trạng và kiến thức - thái độ - thực hành về bênh răng miêng của học sinh tiểu học tai huyên Văn Chấn tỉnh Yên Bái năm 2009, in Luận văn thạc sỹ y học. 2009, Trường đại học Y Dược - Đại học Thái Nguyên: Thái Nguiyên.

4. Mai Thị Liên, Thực trạng bệnh răng miệng và kiến thức, thái độ, thực hành phòng chống bệnh răng miệng của học sinh lớp 5 tại hai trường tiểu học thành phố Nam Định, năm 2013. 2013, Đại học Y Dược Thái Bình.

5. Nguyê̂n Hữu Thiênn, Kiến thức, thái đô, thực hành chăm sóc răng miệng và kết quả hướng dẫn chải răng ở học sinh lớp 4 tại hai trường Tiểu học thành phố Thái Bình, năm 2016, in Luânn văn thạc sĩ YTCC. 2016, Đại học Y Dược Thái Bình.

6. Đào Thi Dung Đào Lê Nam Trung, Ta Thúy Loan, Thực trạng sức khỏe răng miệng và kiến thức, thái độ, hành vi về chăm sóc sức khỏe răng miệng của học sinh lớp 5 trường tiểu học Tiên Dương - Đông Anh, Hà Nội. Tạp chí Y học thực hành, 2010. 2(705): p. 3-6. 